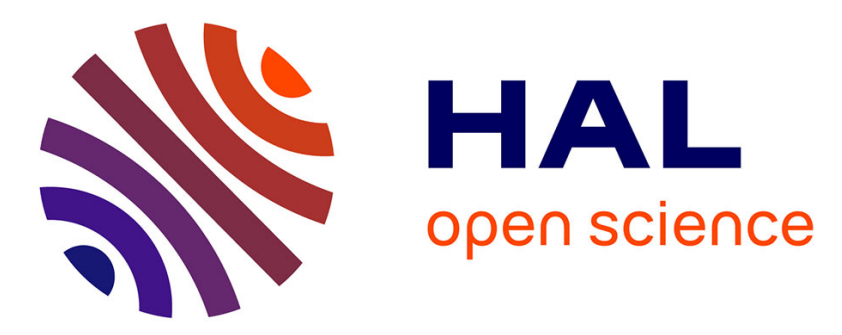

\title{
Western Iberian winter wind indices based on significant wind events
}

\author{
E. Mason, A. M. P. Santos, J. Peliz
}

\section{To cite this version:}

E. Mason, A. M. P. Santos, J. Peliz. Western Iberian winter wind indices based on significant wind events. Ocean Science Discussions, 2005, 2 (2), pp.105-127. hal-00298587

\section{HAL Id: hal-00298587 \\ https://hal.science/hal-00298587}

Submitted on 11 Apr 2005

HAL is a multi-disciplinary open access archive for the deposit and dissemination of scientific research documents, whether they are published or not. The documents may come from teaching and research institutions in France or abroad, or from public or private research centers.
L'archive ouverte pluridisciplinaire HAL, est destinée au dépôt et à la diffusion de documents scientifiques de niveau recherche, publiés ou non, émanant des établissements d'enseignement et de recherche français ou étrangers, des laboratoires publics ou privés. 
Western Iberian winter wind indices

E. Mason et al.

\section{Western Iberian winter wind indices based on significant wind events}

\section{E. Mason ${ }^{1}$, A. M. P. Santos ${ }^{1}$, and Á. J. Peliz ${ }^{2}$}

${ }^{1}$ Instituto de Investigação das Pescas e do Mar, Av. Brasília, 1449-006 Lisboa, Portugal

${ }^{2}$ Departamento de Física, Universidade de Aveiro, 3810-193 Aveiro, Portugal

Received: 7 March 2005 - Accepted: 16 March 2005 - Published: 11 April 2005

Correspondence to: E. Mason (emason @ipimar.pt)

(c) 2005 Author(s). This work is licensed under a Creative Commons License.
Title Page

Abstract

Introduction

Conclusions

References

Tables

Figures

14

$>1$

4

Back

Close

Print Version

Interactive Discussion

EGU 


\section{Abstract}

Wind speed data obtained from the National Centers for Environmental Prediction (NCEP) Reanalysis project are used to construct winter (November-March) wind indices for the western Iberian Peninsula. The data used represent a $2.5^{\circ}$ square area, 5 centred at $41.0^{\circ} \mathrm{N}, 9.4^{\circ} \mathrm{W}$, over the period 1948-2003. The NCEP data are well correlated with a time-series (1980-2001) of wind measurements from the Cape Carvoeiro lighthouse on the western Portuguese coast $\left(39.4^{\circ} \mathrm{N}, 9.4^{\circ} \mathrm{W}\right)$. The new indices, of which there are four corresponding to northerlies, easterlies, southerlies and westerlies, constitute measures of numbers of significant wind event days, where a significant wind event is defined to be 4 or more consecutive days of wind speeds exceeding $4 \mathrm{~m} \mathrm{~s}^{-1}$. Results show both intra- and inter-annual variations in the numbers of significant wind event days, as well as clear decadal trends. A comparison between a hybrid index, composed of the numbers of significant northerly and easterly wind event days - both promote offshore transport, which is thought to have a negative impact on 15 pelagic fish recruitment - and western Iberian sardine catch data, reveal an extensive period of significant negative correlation. The relationship over the most recent period, 1999-2000, is unclear.

\section{Introduction}

The links between coastal upwelling and the biological productivity that takes place 1968; Brink, 1998). A disproportionate percentage of this productivity occurs in coastal upwelling areas, which occupy just $1 \%$ of the area of the world's oceans, and yet account for $20 \%$ of global fish production (Cushing, 1971). Located along eastern ocean boundaries, the principal coastal upwelling areas of the world (northwest and southwest Africa, the coast of Peru, the west coast of North America) share a common feature: quasi-permanent, intense equatorward winds. Stress resulting from these
OSD

2, 105-127, 2005

Western Iberian winter wind indices

E. Mason et al.

Title Page

Abstract Introduction

Conclusions References

Tables Figures

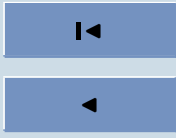

-1

Back

Close

Full Screen / Esc

Print Version

Interactive Discussion

EGU 
alongshore winds causes an Ekman flow (Ekman, 1905) of light surface water away from the coast, which is replaced near shore by the upwelling of dense, cold, nutrientrich water from below (e.g. Gill, 1982). Variations in wind forcing between and within the individual regions strongly affect their biological productivity, although other factors 5 such as variations in bathymetry, latitude, and temperature also have an influence.

Understanding the effects of wind forcing is therefore a fundamental objective, which has attracted particular attention from fisheries scientists as a result of the great socioeconomic importance of fisheries resources. A common approach that reflects the perceived impact of the upwelling on the survival and/or mortality of the biota, has been 10 the use of indices that seek to empirically relate the strength of the upwelling-favourable wind stress to the biological productivity (e.g. Bailey, 1981). In most cases, the index is composed of a simple measure of transport velocity, or volume transport, both of which are derived from the wind stress (see Bakun, 1973). However, this approach permits the neglect of a potentially important factor, which is the temporal delay between the onset of upwelling-favourable winds and the development of a steady-state upwelling situation in the coastal ocean. In this paper we report on our work into a simple index, based on the characteristics of the western Iberian shelf, which seeks to account for upwelling-development delay. The numerical modelling study by Peliz et al. (2003) found that, over the western Iperian Peninsula (IP), northerly winds exceeding $4 \mathrm{~m} \mathrm{~s}^{-1}$ are required for at least 4 consecutive days to achieve steady-state upwelling. We adopt these parameters in the creation of our northerly-wind upwelling index. Advection estimates may be made for these values, using $v_{E k}=\tau /(\rho d f)$, where $v_{E k}$ is the Ekman velocity, $\tau$ the wind stress, $\rho$ the density, $f$ the Coriolis parameter, and $d$ the Ekman depth. The wind stress is determined using $\tau=\rho_{a} C_{d} w^{2}$, with $\rho_{a}=1.22 \mathrm{~kg} \mathrm{~m}^{-3}$ being an 25 average air density, the drag coefficient $C_{d}=0.0012$, and $w$ the wind speed in $\mathrm{m} \mathrm{s}^{-1}$. Ekman depths, $d$, of 10 and $20 \mathrm{~m}$ result in advective distances of approximately 8000 and $4000 \mathrm{~m}$, respectively. We go on to extend the use of the 4-day, $4 \mathrm{~m} \mathrm{~s}^{-1}$ parameters to the creation of a southerly/downwelling-favourable wind index; an easterly/offshore wind index; and a westerly/onshore wind index. The indices described in this paper

\section{Western Iberian} winter wind indices

E. Mason et al.

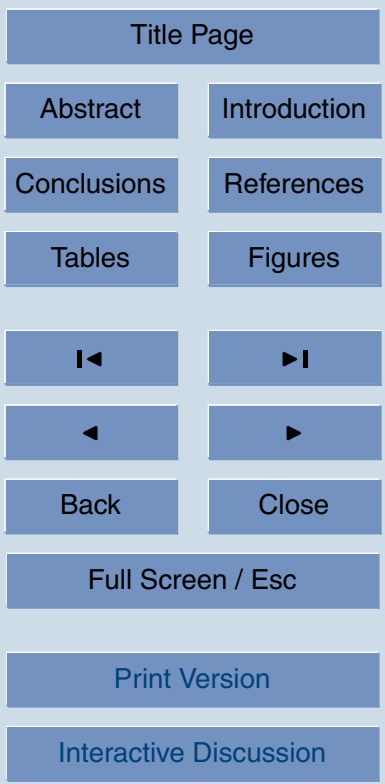

EGU 


\section{Methods}

A time series (1948-2003) of daily-averaged $u$ and $v$ wind velocity components (10 m above the surface) were obtained from the National Centers for Environmental Prediction (NCEP) website. The NCEP Reanalysis project (Kistler et al., 2001) provides a retroactive record of global analyses of atmospheric fields. The NCEP data obtained were drawn from a single grid point located at $41.0^{\circ} \mathrm{N}, 9.4^{\circ} \mathrm{W}$, which is just above the 200-m isobath off the western IP. To assess the extent to which the NCEP data are representative of the wind variability of the region, a time series (1980-2001) of wind velocities measured at the Cape Carvoeiro lighthouse were analysed. This station is located at $39.4^{\circ} \mathrm{N}, 9.4^{\circ} \mathrm{W}$, some $80 \mathrm{~km}$ north of Lisbon, Portugal, and about $180 \mathrm{~km}$ south of the NCEP grid point. The data were provided by the Portuguese Meteorological Office. Records were taken every 3 to $6 \mathrm{~h}$, barring September 1996 to January 152000 when hourly samples were taken. All data were averaged to provide a single daily value for each variable. Figure 1a shows the wind evolution at Cape Carvoeiro for 1997. Note the summer upwelling season described by consistent northerly winds from June through September. Figure 1b shows a comparative stick plot of the NCEP $u$ and $v$ winds for the same year as Fig. 1a. A high degree of visual similarity is evident between the two plots; note again the summer upwelling period.

\subsection{Vector correlation}

A more rigorous measure of the correlation between the NCEP and Carvoeiro wind data sets was provided by application of the vector correlation technique developed by Jupp and Mardia (1980), and since advocated by, for example: Crosby et al. (1993) and Breaker et al. (2003). As such this is the current generally accepted statistic for

\section{Western Iberian winter wind indices}

E. Mason et al.

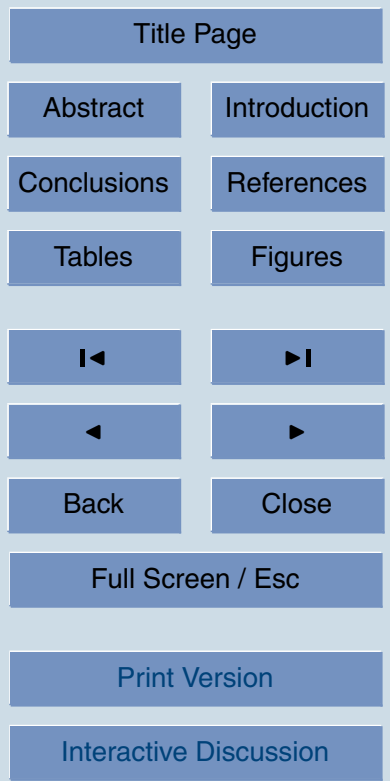

EGU 
quantifying the degree of "similarity" or linear correlation between multiple vector time series. A selection of the resulting correlations for yearly samples is shown in Table 1, together with the accompanying means and standard deviations. The vector correlation, denoted by $\rho^{2}$, is zero when the two vector time series are independent, and $\rho^{2}=2$ 5 when they are linearly related. The range of $\rho^{2}$ values that we obtained from the full series (1980-2001) is 0.7 to 1.7. Following Breaker et al. (2003), the critical $\rho^{2}$ value is 0.34 at the $5 \%$ level of significance. Note that for 1997, shown in the stick plots of Fig. 1 , $\rho^{2}=1.4$. There is, therefore, a high degree of correlation between the data, particularly given the fact of their distinct origins (derived versus measured). The mean values in

10 Table 1 are generally in good agreement, with the NCEP values marginally the greater: the largest difference is $0.87 \mathrm{~m} \mathrm{~s}^{-1}$ for the $u$ component in 1999. The NCEP standard deviations are also consistently greater than those from Cape Carvoeiro; we suspect the cause lies in differences between how the respective daily averages were calculated. Given these positive results, we continued our work using the NCEP data, which offered a longer time series with consistent temporal sampling, as well as representation of open ocean conditions. Nevertheless, it is important to stress that differences do (and should) exist between the data: Freilich and Dunbar (1999) stated that high correlation does not preclude the existence of systematic speed and directional differences between the two vector data sets.

\subsection{Extraction of significant wind events}

The NCEP wind data were processed so as to extract into spreadsheets the numbers, per month per year, of (a) significantly upwelling-favourable wind event (SUFWE) days; (b) significantly downwelling-favourable wind event (SDFWE) days; (c) significant offshore wind event (SOFWE) days; and (d) significant onshore wind event (SONWE)

\section{Western Iberian} winter wind indices

E. Mason et al.

\section{Title Page}

Abstract Introduction

Conclusions

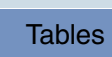

References

Tables

Figures

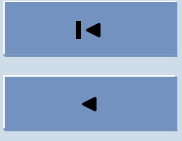

$\rightarrow$

Back

Close

Full Screen / Esc

Print Version

Interactive Discussion

EGU defined a significant wind event to be any period of 4 or more consecutive days where the wind speed in the desired direction equalled or exceeded $4 \mathrm{~m} \mathrm{~s}^{-1}$. An example of this process can be seen in Fig. 2: Fig. 2a shows the full evolution of the wind through 
the winter of 1999/2000; while Fig. 2b shows the only two SUFWE events - of 4 and 10 days, respectively - that occurred during this period. Our choice of limits is in accordance with the findings of Peliz et al. (2003) for the establishment of a steady-state upwelling situation over the western Iberian shelf, as was explained in the previous 5 section. Clearly however, opportunities exist for other combinations of parameters.

\section{Results}

\subsection{Upwelling-favourable wind index}

Figure 3 shows the variability in the number of days of significantly upwelling-favourable wind events (SUFWE) over the winter months (November-March) for the years 1948

through 2003. It is apparent that there are considerable intra- and interannual variations in the numbers of SUFWE days. 1967 had the highest count with 35 SUFWE days; counts of 0 occurred on five occasions: 1963, 1976, 1995, 1997 and 2000. From about the mid-1980s there appears to be a general decrease in the number of SUFWE days; this trend is evident from the red line in Fig. 3 which is a 5-year running average of the total SUFWE day number for each winter season. Figure 3 also shows that SUFWE days during November and December were more common in the third quarter of the last century than they were in the final quarter: in the years 1948 to 1975 there were 3 November-December periods without SUFWEs; yet, between 1976 and 2003 there were 15 such periods.

For a better appreciation of the intra-annual variability, Fig. 4 shows 11-year running averages for the five individual winter months. These plots confirm the aforementioned trend for the November and December months: before the early 1970s these months have an 11-year mean of at least 3 days of significantly-favourable upwelling winds; after this period, the 11-year mean drops sharply to between 1 and 3 days. The trends for the two months appear to follow each other. There is also similarity in the trends for January and February. These both have some of their highest values of 3 to 4 days of
OSD

2, 105-127, 2005

Western Iberian winter wind indices

E. Mason et al.

Title Page

Abstract Introduction

Conclusions References

Tables Figures

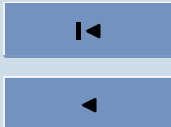

$\rightarrow$

Back

Close

Full Screen / Esc

Print Version

Interactive Discussion

EGU 
significantly-favourable upwelling winds in the 1950s, with their lowest values of under 1 day subsequently occurring in the 1960s. They both peak again ( 3 to 4 days) in the early 1980s, before falling to about 2 days in the late 1990s. When considering the plots of the four months so far discussed, it is clear that in the third quarter of the 5 last century there was significantly more divergence in the number of SUFWE days between the months, than in the final quarter. Indeed, all four months display some convergence in their trends after 1975, particularly in the 1990s. The 11-year running average for March is somewhat different from the months so far discussed. March has the highest peaks, 6 SUFWE days, of all the months; these peaks occur in the late 101960 s and at the end of the 1980s. On either side of each peak there are lows that go down to between 1 and 2 days. The March values appear to be in opposite phase to those for January and February. Figure 4 shows that for all five months, at the period approaching the end of the 1990s, the 11-year mean number of SUFWE days is 2 or below; this situation does not occur at any other preceding point in the time series.

15 3.2. Offshore, onshore and downwelling-favourable wind indices

Figure 5 compares the (November-March) upwelling-favourable (SUFWE) wind values with similarly-processed indices of offshore (SOFWE), onshore (SONWE), and downwelling-favourable (SDFWE) wind data. The plots use 11-year running averages, for which the decreasing trend in the numbers of upwelling-favourable days that has 20 been described above is especially apparent. Numbers of offshore-wind days are substantially lower than for the other three wind directions, for much of the time series; it is only in the late 1980s where they rise and converge toward the decreasing upwellingwind values. After 1990 the offshore-wind values start to decrease again. In contrast, the numbers of onshore-wind days, which range between 17 and 25 days, exceed 25 those for upwelling, downwelling, and offshore winds. It is only at the beginning of the 1990s that they drop down to 15 days; at this time the numbers of downwelling days increase. There is the suggestion of an inverse relationship between the numbers of upwelling days and downwelling days, with peaks and troughs in the respective

\section{Western Iberian winter wind indices}

E. Mason et al.

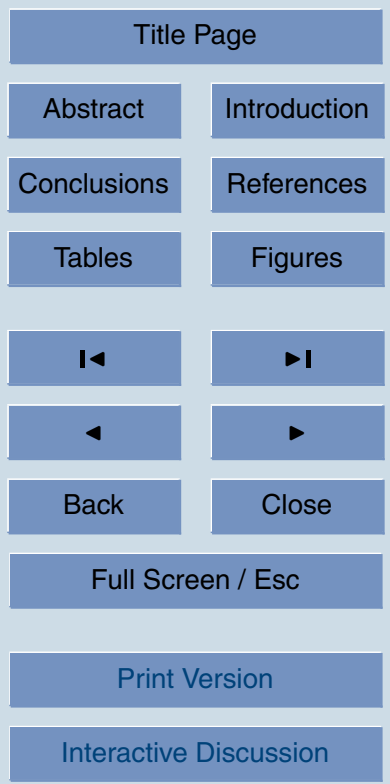

EGU 
time series roughly coincident in 1962, 1969-1970 and 1979-1981. However, from the 1980s onwards the relationship is less clear as the aforementioned decrease in SUFWE days takes place.

\section{Discussion}

5 The results obtained suggest that the total duration of significant winter upwelling wind events off western Iberia, when summed over the months November through March, have been declining in number since the 1970s; this trend is particularly true for the early months (November and December) of the season, but it is also apparent for January and February. We believe that these results complement rather than contradict those of Borges et al. (2003), who describe an increase in upwelling-favourable wind activity since the 1970s, using January-March data. However, our results indicate that any increase observed (over the 1980s and 1990s) in an index based on wind data from January through March, is likely to be a product only of the large increases that occurred in March, as were shown in Fig. 4. Santos et al. (2005) report a weak but persistent upwelling anomaly during winter, off the lberian coast for the period 19922001; their index was based on the magnitude of the coastal zonal gradient of SST. The explanation for this second apparent contradiction of our results may be the threshold parameter of $4 \mathrm{~m} \mathrm{~s}^{-1}$ that we adopted - persistent winds with speed less than this value do not show up in our index. A further explanation may be the role that offshore winds
OSD

2, 105-127, 2005

Western Iberian winter wind indices

E. Mason et al.

Title Page

Abstract Introduction

Conclusions References

Tables

Figures

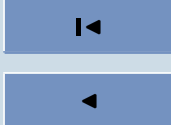

$\rightarrow$

Back

Close

Full Screen / Esc

Print Version

Interactive Discussion

EGU 
Previous studies such as Dickson et al. (1988) and Borges et al. (2003), have found there to be significant inverse, negative relationships between upwelling related indices and sardine catches off western Iberia, over the second half of the last century. It is 5 suggested that negative correlations arise from the (wind-induced) offshore transport of eggs and larvae away from coastal nursery grounds, where survival may be compromised by limited food availability and by predation (e.g. Bailey, 1981; Parrish et al., 1981). Borges et al. (2003) also report highly significant correlations between the wind conditions and a winter (January-March) North Atlantic Oscillation (NAO) index. In

10 Fig. 6 we compare annual sardine catches (year+1, following Borges et al., 2003) with a 5-year (backward) running average of a hybrid index of the SUFWE and SOFWE (offshore wind) indices, for the years 1952-2000. The motivation for a hybrid index stems from a study by Tilburg (2003), who demonstrated that across-shelf winds can induce across-shelf transport in the upper few meters of the water column; he stated that over 15 the inner shelf, across-shelf winds may take precedence over along-shelf winds in the generation of across-shelf surface velocities. Hence, non-inclusion of offshore winds in the present index would imply neglect of a significant potential contributor to offshore transport (which is thought to have a negative impact on sardine recruitment). The sardine catch data relate to the western IP region, and were taken from the ICES "Working 20 Group on the Assessment of Mackerel, Horse Mackerel, Sardine and Anchovy" (ICES, 2003); see Borges et al. (2003) for further discussion of these data. The catch data reflect the current low level of abundance of the Iberian sardine stock in compare to levels over the last half-century; these changes have been documented by Stratoudakis et al. (2003).

25 The time series in Fig. 6 may be divided into two separate and distinct periods. The first period occurs between the mid-1950s and the late-1970s, and is characterised by large, quasi-decadal, fluctuations in both the wind and the catch data. The relationship between catch and numbers of significant wind days appears to be negative. The

\section{Western Iberian winter wind indices}

E. Mason et al.

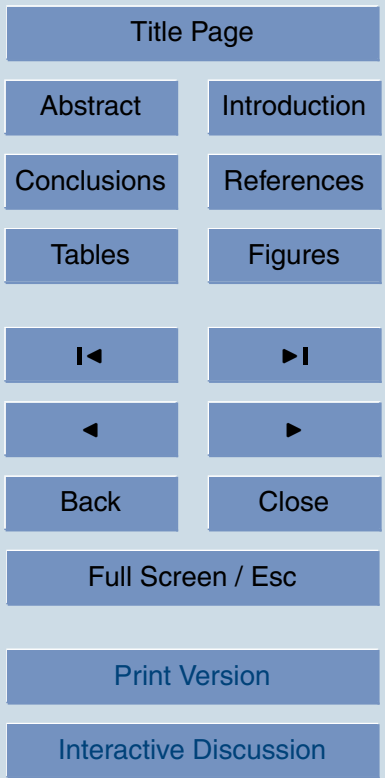

EGU 
deepest trough in the wind data, with values of just over 22 days, occurs in 1960; over the next 3 years it remains at this level, and is accompanied by high catch values of 120000-140000 tons. Over the course of the 1960s, the numbers of significant wind days steadily increase, reaching a peak of nearly 43 days in 1970 . The catch data attain 5 their highest peak of $\sim 160000$ tons in 1964; by 1969 they have fallen to 60000 tons, a 20-year low. This is a dramatic decline in catch, which the increasing numbers of significant wind days in our hybrid index over this period, appear to explain rather well. Dickson et al. (1988) reported such a negative relationship between their upwelling index (for Porto at $41^{\circ} \mathrm{N}$ ) and annual Iberian sardine catch (ICES area IXa), for the 10 period 1950-1984. Their index was an average of the April upwelling over the 3 years preceding the catch year. There is considerable similarity between Fig. 15 of Dickson et al. (1988) and our first period shown in Fig. 6. Their data show the aforementioned trough in the upwelling in the early 1960s and the coincident high in sardine catches. After 1975 their data continue to show a negative relationship until the end of their time 15 series in 1984.

The second period covers the years $\sim 1980$ through 2000 . Here, the relationship between sardine catch and significant wind days appears to remain negative; however, the amplitude of the fluctuations is smaller for the wind, and also, significantly, for the catches, when compared with the earlier (first) period. Over the 1970s the catch generally increases, whilst the significant wind days decrease from their 1970 high. This suggests a recovery of the sardine stock - possibly afforded by more favourable environmental conditions - following their dramatic decline in the late 1960s. During the 1980 s the numbers of significant wind days remain within the relatively narrow range of 25 to 34 days; catches, meanwhile, oscillate between 85000 and 112000 tons, approximately. In the 1990s, catch values generally decline, reaching nearly 65000 tons in 2000. The wind data also show a decreasing trend, such that it appears there is a breakdown in the negative relationship thus far observed, particularly between 1994 and 1997.

Regression analyses were performed on the data used in Fig. 6, for which results
OSD

2, 105-127, 2005

\section{Western Iberian} winter wind indices

E. Mason et al.

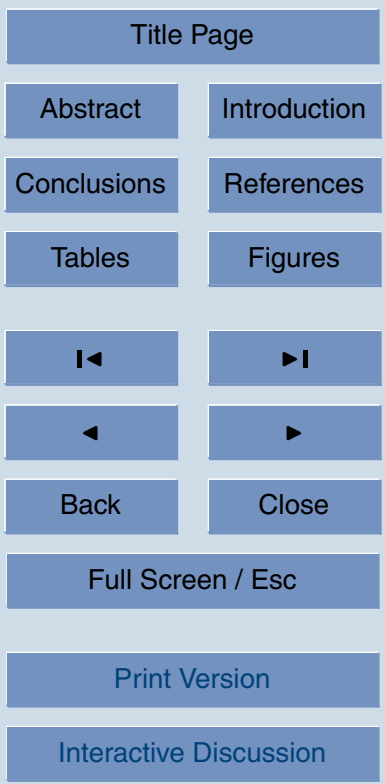

EGU 
are shown in Table 2. It was found that the negative relationship between the hybrid wind index and sardine catch, between 1952 and 2000, is below the $95 \%$ level of significance $(P=0.092)$. However, we believe this is a useful result, given the large scatter in the data $\left(R^{2}=0.059\right)$, and additional independent factors not accounted for by 5 the wind index, such as fishing effort, and also, importantly, other oceanographic processes: Santos et al. (2004) describe a situation that occurred off western Iberia where shelf-slope convergence zones (between the Iberian Poleward Current and the Western Iberia Buoyant Plume) were observed to retain sardine larvae within the favourable coastal environment, despite the action of "unfavourable" upwelling-favourable winds.

10 This event happened in February 2000, which corresponds to the breakdown in the present index. Indeed, we show (Table 2) that if the years 1999 and 2000 are excluded from the regression, the relationship does become significant $(P=0.046)$, and the level of significance continues to increase as more data from the late 1990s are excluded; $P=0.005$ for the years 1952 to 1992 , for instance.

15 Overall, these results show that there is a very good relationship between our hybrid wind index and annual Iberian sardine catches, although the relationship appears to be weaker in recent years. We are not sure of the reasons for the present uncertainty, but they may include the demonstrated anomalous wind behaviour (see Figs. 3, 4 and 5, and accompanying text) during this time, and also the influence of non-wind 20 related oceanographic processes as mentioned above (and described by Santos et al., 2004). A dramatic failure of an upwelling index also occurred during the 1999/2000 austral summer: Roy et al. (2001) describe the unexpectedly high anchovy recruitment recorded off western South Africa in 2000; this was in contradiction to expectations for a particularly poor spawning season, based on established upwelling/recruitment indices for that region (Boyd et al., 1998). Rather than conceding failure of the index, the researchers were prompted to make a close investigation into the short-term environmental variability in order to reconcile the exceptional recruitment with previous findings - in which they were successful. These events demonstrate the additional value of the use of indices: when the index fails, investigators receive a strong signal

OSD

2, 105-127, 2005

Western Iberian winter wind indices

E. Mason et al.

Title Page

Abstract Introduction

Conclusions

Tables

References

Figures

14

4

Back

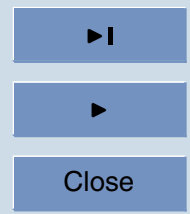

Full Screen / Esc

Print Version

Interactive Discussion

EGU 
that it is time to take a closer look at the local processes, to find out what caused the system to depart from its expected behaviour. It is this knowledge that increases understanding of the system as a whole (and incidentally may lead to a further refinement of the index).

5 Table 2 also includes regressions, for comparison with the hybrid index, that use the SUFWE index, and also the winter (December-March) North Atlantic Oscillation (NAO; Hurrell, 1995) index. The SUFWE regressions become significant only by excluding the years 1995-2000 ( $P=0.043$ in 1994). This may be explained by referring again to Fig. 5, where we see that during the late 1990s offshore wind days were relatively 10 high, whilst upwelling-favourable wind days were in decline. Hence, the hybrid index performs better because it incorporates the offshore wind component. The NAO regressions are not significant at the $95 \%$ level.

We may speculate that the environmental changes indicated by our results, are in the process of inducing a sardine "regime" shift. Regimes are described as periods of high 15 or low (sardine) abundance, and are ubiquitous features of the sardine-populated waters around the globe; their occurrence and significance is discussed by Lluch-Belda et al. (1989). The regime concept implies the persistence of an inherently stable relationship between the environment and the biota (sardines) over long periods. Our results suggest that this may have been the case from 1952 until 1999, with the present situation remaining unclear. However, there are many factors beyond the wind forcing that also influence annual catch statistics, and their influence has not been accounted for within this study.

\section{Conclusions}

A new type of wind index for the western Iberian Peninsula has been developed. The 25 index describes numbers of significant wind event days, where a significant wind event is defined to be a wind event of sufficient intensity and duration to promote the formation of a steady-state upwelling situation (arising from northerly winds over the western

\section{Western Iberian winter wind indices}

E. Mason et al.

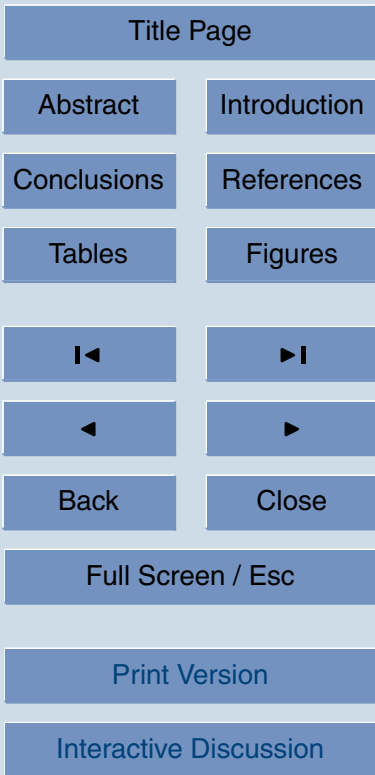


Iberian shelf): the limits used are wind speeds of $4 \mathrm{~m} \mathrm{~s}^{-1}$ or more, over at least a 4-day period. The same limits are also conveniently applied for the cases of downwelling, onshore, and offshore winds. Examination of the indices reveals both intra- and interannual variations in the numbers of days of significant wind events, for all four wind 5 orientations. Our upwelling-favourable northerly wind index suggests a general decline in upwelling since the 1970s, apparently in contradiction to other studies. However, we show that the variability between individual months may be sufficiently strong to suggest increased or decreased upwelling, depending on the months used to generate the index.

10 Comparison of a hybrid index, composed of upwelling-favourable and offshore winds with coincident records of Iberian sardine catches, reveals a $\sim 47-y e a r$ period of significant negative correlation. Negative correlations have been obtained in previous studies from the western Iberian region, and have been attributed to the loss offshore of sardine eggs and larvae as a result of offshore Ekman transport. The relationship between the hybrid index and sardine catches becomes less clear over the last few years of the catch record. The hybrid index outperforms the upwelling-favourable wind index, and also the North Atlantic Oscillation index. Given these positive results, we recommend continued experimentation with the hybrid index idea in other upwelling regions.

Acknowledgements. E. Mason is supported by the project PELAGICOS (FCT PLE/13/00). 20 NCEP Reanalysis data were provided by the NOAA-CIRES Climate Diagnostics Center, Boulder, Colorado, USA, from their Web site at http://www.cdc.noaa.gov/. Cape Carvoeiro wind data were provided by the Portuguese Meteorological Office in Lisbon, Portugal. We would like to thank both P. Oliveira and K. Ganias for their helpful comments and discussion that have added to the quality of this paper.

\section{References}

Bailey, K. M.: Larval transport and recruitment of Pacific hake (Merluccius-productus), Mar. Ecol. Prog. Ser., 6, 1-9, 1981.

Western Iberian winter wind indices

E. Mason et al.

\section{Title Page}

Abstract Introduction

Conclusions References

Tables Figures

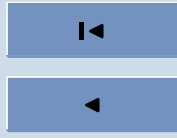
- I Back Close

Full Screen / Esc Print Version

Interactive Discussion

EGU 
Bakun, A.: Coastal upwelling indices, west coast of North America, 1946-1971, NOAA Tech. Rep., NMFS SSRF-671, 1973.

Borges, M. F., Santos, A. M. P., Crato, N., Mendes, H., and Mota, B.: Sardine regime shifts off Portugal: a time series analysis of catches and wind conditions, Sci. Mar., 67, 235-244, 52003.

Boyd, A. J., Shannon, L. J., Schulein, F. H., and Taunton-Clark, J. T.: Global versus local changes in upwelling systems, ORSTOM, Paris, 1998.

Breaker, L. C., Gemmill, W. H., de Witt, P. W., and Crosby, D. S.: A curious relationship between the winds and currents at the western entrance of the Santa Barbara Channel, J. Geophys.

10 Res., 108, 2003.

Brink, K. H.: The Global Coastal Ocean: Processes and Methods, Wiley, New York, 1998.

Crosby, D. S., Breaker, L. C., and Gemmill, W. H.: A proposed definition for vector correlation in geophysics: Theory and application, J. Atmos. Ocean. Tech., 10, 355-367, 1993.

Cushing, D. H.: Upwelling and the production of fish, University of Wisconsin Press, Wisconsin, 1971.

Dickson, R. R., Kelly, P. M., Colebrook, J. M., Wooster, W. S., and Cushing, D. H.: North winds and production in the eastern North-Atlantic, J. Plankton Res., 10, 151-169, 1988.

Ekman, V. W.: On the influence of the earth's rotation on ocean currents, Arkiv för Matematik, Astronomi och Fysik, 2, 1905.

20 Freilich, M. H. and Dunbar, R. S.: The accuracy of the NSCAT 1 vector winds: Comparisons with National Data Buoy Center buoys, J. Geophys. Res., 104, 11231-11246, 1999.

Gill, A. E.: Atmosphere-Ocean Dynamics, Academic Press, London, 1982.

ICES: Report of the working group on the assessment of mackerel, horse mackerel, sardine and anchovy, ICES CM 2003/ACFM:7, 2003.

Jupp, P. E. and Mardia, K. V.: A general correlation-coefficient for directional-data and related regression problems, Biometrika, 67, 163-173, 1980.

Kistler, R., Kalnay, E., Collins, W., Saha, S., White, G., Woollen, J., Chelliah, M., Ebisuzaki, W., Kanamitsu, M., Kousky, V., van den Dool, H., Jenne, R., and Fiorino, M.: The NCEP-NCAR 50-year reanalysis: Monthly means CD-ROM and documentation, Bull. Amer. Meteor. Soc., $30 \quad 82,247-267,2001$.

Lluch-Belda, D., Crawford, R. J. M., Kawasaki, T., MacCall, A. D., Parrish, R. H., Schwartzlose, R. A., and Smith, P. E.: Worldwide fluctuations of sardine and anchovy stocks - the regime problem, S. Afr. J. Marine Sci., 8, 195-205, 1989.

\section{Western Iberian winter wind indices}

E. Mason et al.

\section{Title Page}

Abstract Introduction

Conclusions

Tables

References

Figures

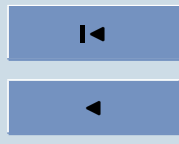

$\rightarrow$

Back

Close

Full Screen / Esc

Print Version

Interactive Discussion 
Parrish, R. H., Nelson, C. S., and Bakun, A.: Transport mechanisms and reproductive success of fishes in the California Current, Biol. Oceanogr., 1, 175-203, 1981.

Peliz, A. J., Dubert, J. S., and Haidvogel, D. B.: Subinertial response of a density-driven eastern boundary poleward current to wind forcing, J. Phys. Oceanogr., 33, 1633-1650, 2003.

5 Santos, A. M. P., Peliz, A., Dubert, J., Oliveira, P. B., Angelico, M. M., and Re, P.: Impact of a winter upwelling event on the distribution and transport of sardine (Sardina pilchardus) eggs and larvae off western Iberia: a retention mechanism, Cont. Shelf Res., 24, 149-165, 2004.

Santos, A. M. P., Kazmin, A. S., and Peliz, A.: Decadal changes in the Canary Upwelling System as revealed by satellite observations: Their impact on productivity, J. Mar. Res., 63, 359-379, 2005.

Smith, R. L.: Upwelling, Oceanogr. Mar. Biol. Ann. Rev., 6, 11-46, 1968.

Stratoudakis, Y., Bernal, M., Borchers, D. L., Borges, M. F., and Cardador, F.: Changes in the distribution of sardine eggs and larvae off Portugal, 1985-2000, Fish. Oceanogr., 12, 49-60, 2003.

\footnotetext{
Tilburg, C. E.: Across-shelf transport on a continental shelf: Do across-shelf winds matter?, J. Phys. Oceanogr., 33, 2675-2688, 2003.
}

\section{OSD}

2, 105-127, 2005

\section{Western Iberian} winter wind indices

E. Mason et al.

\section{Title Page}

Abstract Introduction

Conclusions

References

Tables

Figures

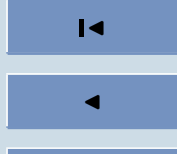

-1

Back

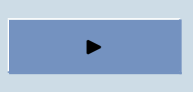

Close

Full Screen / Esc

Print Version

Interactive Discussion

EGU 
2, 105-127, 2005

Western Iberian winter wind indices

E. Mason et al.

Table 1. Selected correlation values $\left(\rho^{2}\right)$ together with means and standard deviations for the wind velocities from the Cape Carvoeiro light station and from the NCEP Reanalysis project.

\begin{tabular}{|c|c|c|c|c|c|c|}
\hline \multirow{2}{*}{ Year } & \multirow{2}{*}{$\rho^{2}$} & \multirow{2}{*}{$\begin{array}{c}\text { Velocity } \\
\text { component }\end{array}$} & \multicolumn{2}{|c|}{ Cape Carvoeiro } & \multicolumn{2}{|c|}{ NCEP } \\
\hline & & & $\bar{x}$ & $\sigma$ & $\bar{x}$ & $\sigma$ \\
\hline \multirow{2}{*}{1987} & \multirow{2}{*}{1.1} & $\mathrm{u}$ & 0.41 & 2.00 & 0.51 & 3.33 \\
\hline & & $\mathrm{v}$ & -0.92 & 3.82 & -0.79 & 4.93 \\
\hline \multirow{2}{*}{1997} & \multirow{2}{*}{1.4} & $\mathrm{u}$ & 0.51 & 2.71 & 0.91 & 3.34 \\
\hline & & $\mathrm{v}$ & -1.07 & 3.66 & -0.23 & 4.63 \\
\hline \multirow{2}{*}{1999} & \multirow{2}{*}{1.7} & $\mathrm{u}$ & -0.23 & 2.41 & 0.64 & 3.48 \\
\hline & & $\mathrm{v}$ & -1.54 & 3.87 & -1.16 & 4.72 \\
\hline \multirow{2}{*}{2000} & \multirow{2}{*}{0.7} & $\mathrm{u}$ & 0.27 & 1.71 & 1.09 & 3.50 \\
\hline & & $\mathrm{v}$ & -0.78 & 3.33 & -0.69 & 4.87 \\
\hline
\end{tabular}

Title Page

Abstract

Introduction

Conclusions

References

Tables

Figures

14

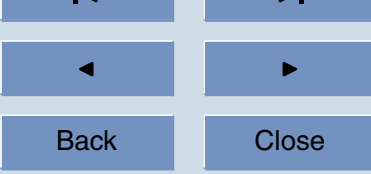

Full Screen / Esc

Print Version

Interactive Discussion

EGU 


\section{Western Iberian} winter wind indices

E. Mason et al.

Table 2. Results of regression analyses performed between the 5-year average hybrid wind index; the 5-year average upwelling-favourable wind index; the North Atlantic Oscillation index; and annual sardine catch data. In all cases, the first year of the time series for the regressions was 1952.

\begin{tabular}{c|c|c|c|c|c|c|c|c|c|c}
\hline \multicolumn{2}{c|}{ End year } & 2000 & 1999 & 1998 & 1997 & 1996 & 1995 & 1994 & 1993 & 1992 \\
\hline \multicolumn{2}{c|}{} & 49 & 48 & 47 & 46 & 45 & 44 & 43 & 42 & 41 \\
\hline Hybrid & $P$ & 0.092 & 0.060 & 0.046 & 0.028 & 0.013 & 0.006 & 0.005 & 0.005 & 0.005 \\
index & $R^{2}$ & 0.059 & 0.075 & 0.085 & 0.105 & 0.136 & 0.165 & 0.179 & 0.184 & 0.187 \\
\hline SUFWE & $P$ & 0.890 & 0.634 & 0.339 & 0.69 & 0.098 & 0.061 & 0.043 & 0.041 & 0.037 \\
index & $R^{2}$ & 0.000 & 0.005 & 0.020 & 0.042 & 0.062 & 0.081 & 0.096 & 0.101 & 0.107 \\
\hline \multirow{2}{*}{ NAO } & $P$ & 0.089 & 0.125 & 0.158 & 0.170 & 0.167 & 0.100 & 0.126 & 0.150 & 0.159 \\
& $R^{2}$ & 0.060 & 0.050 & 0.044 & 0.042 & 0.044 & 0.063 & 0.056 & 0.051 & 0.050 \\
\hline
\end{tabular}

Title Page

\section{Abstract}

Introduction

Conclusions

References

Tables

Figures
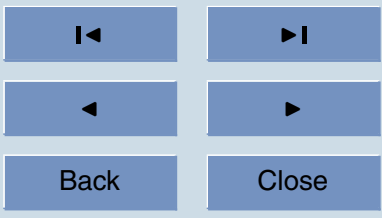

Full Screen / Esc

Print Version

Interactive Discussion

EGU 
2, 105-127, 2005

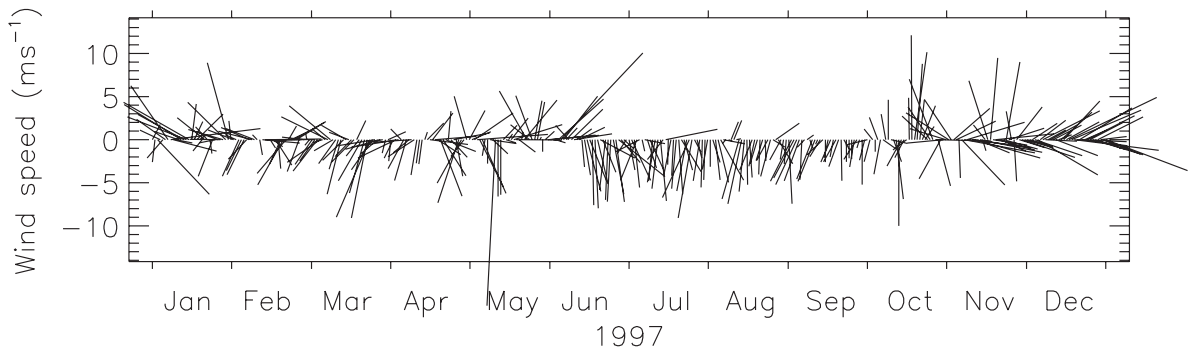

(a)

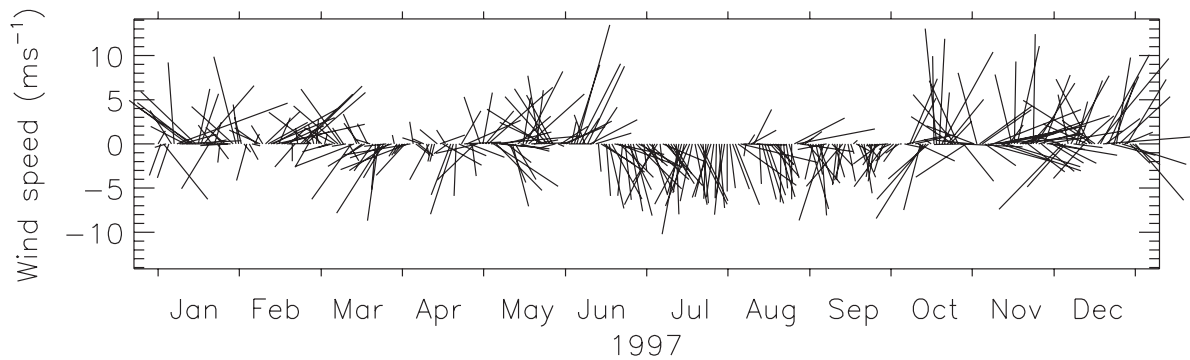

(b)

Fig. 1. Stick plots of 1997 wind velocities measured at (a) the Cape Carvoeiro light station $\left(39.4^{\circ} \mathrm{N}, 9.4^{\circ} \mathrm{W}\right)$ and $\left(\right.$ b) as provided by NCEP for $41.0^{\circ} \mathrm{N}, 9.4^{\circ} \mathrm{W}$.

Western Iberian winter wind indices

E. Mason et al.

Title Page

Abstract

Introduction

Conclusions

References

Tables

Figures

14

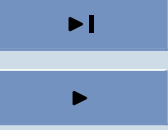

Back

Close

Full Screen / Esc

Print Version

Interactive Discussion

EGU 


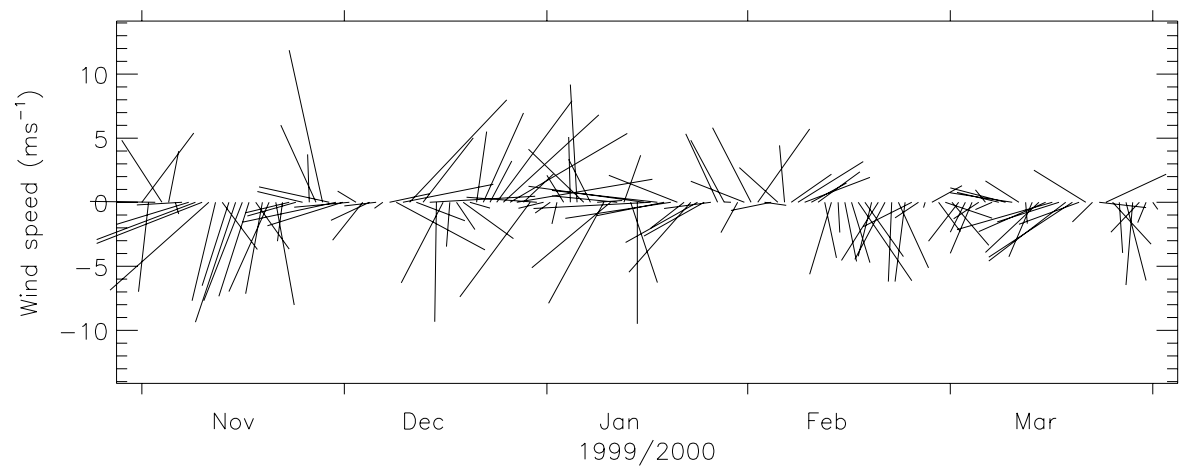

\section{OSD}

2, 105-127, 2005

\section{Western Iberian winter wind indices}

E. Mason et al.

\section{Title Page}

\section{Abstract}

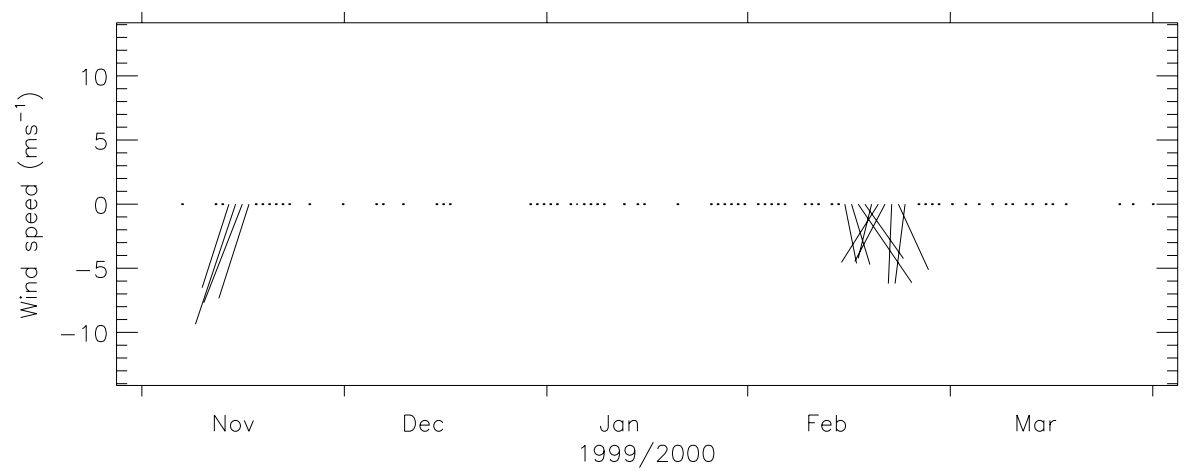

Fig. 2. Stick plots of wind velocities from NCEP for the winter period, November 1999 through March 2000: (a) shows the full wind evolution; while (b) shows just the 2 significant upwellingfavourable wind events that occurred during this period.
Conclusions

Tables

References

Figures

14

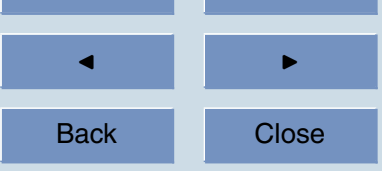

Full Screen / Esc

Print Version

Interactive Discussion 


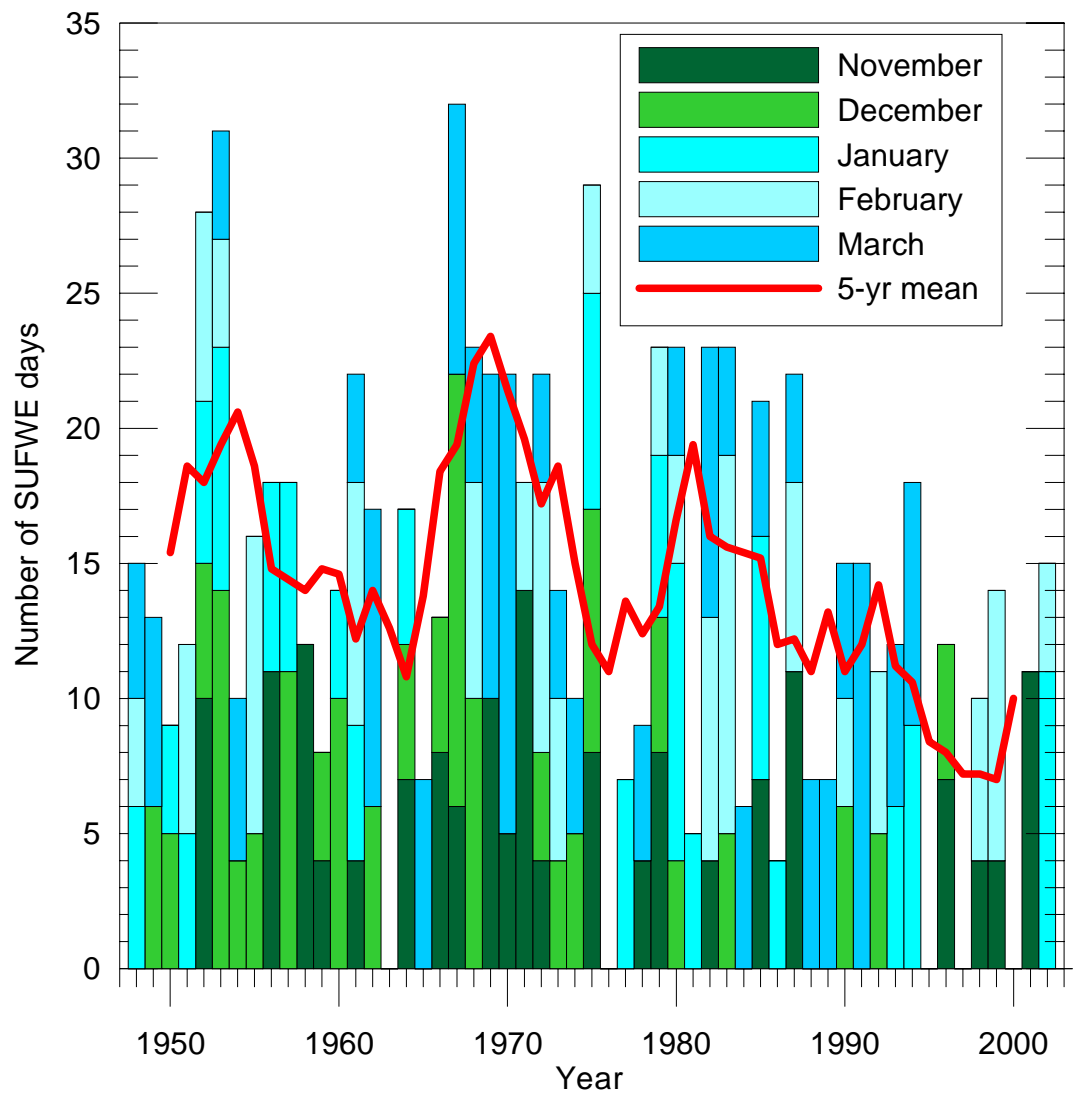

OSD

2, 105-127, 2005

Western Iberian winter wind indices

E. Mason et al.

\section{Title Page}

Abstract

Introduction

Conclusions

References

Tables

Figures

14

- I

Back

Close

Full Screen / Esc

Print Version

Fig. 3. Bar plot showing the numbers of significantly upwelling-favourable days (SUFWE) over the winter months for the years $1948-2003$, at $41.0^{\circ} \mathrm{N}, 9.4^{\circ} \mathrm{W}$. Note that a winter season (in the northern hemisphere) encompasses two different years so that, for example, 1952 on the $\mathrm{x}$-axis of the figure refers to November and December of 1952; but January and February of 1953. 


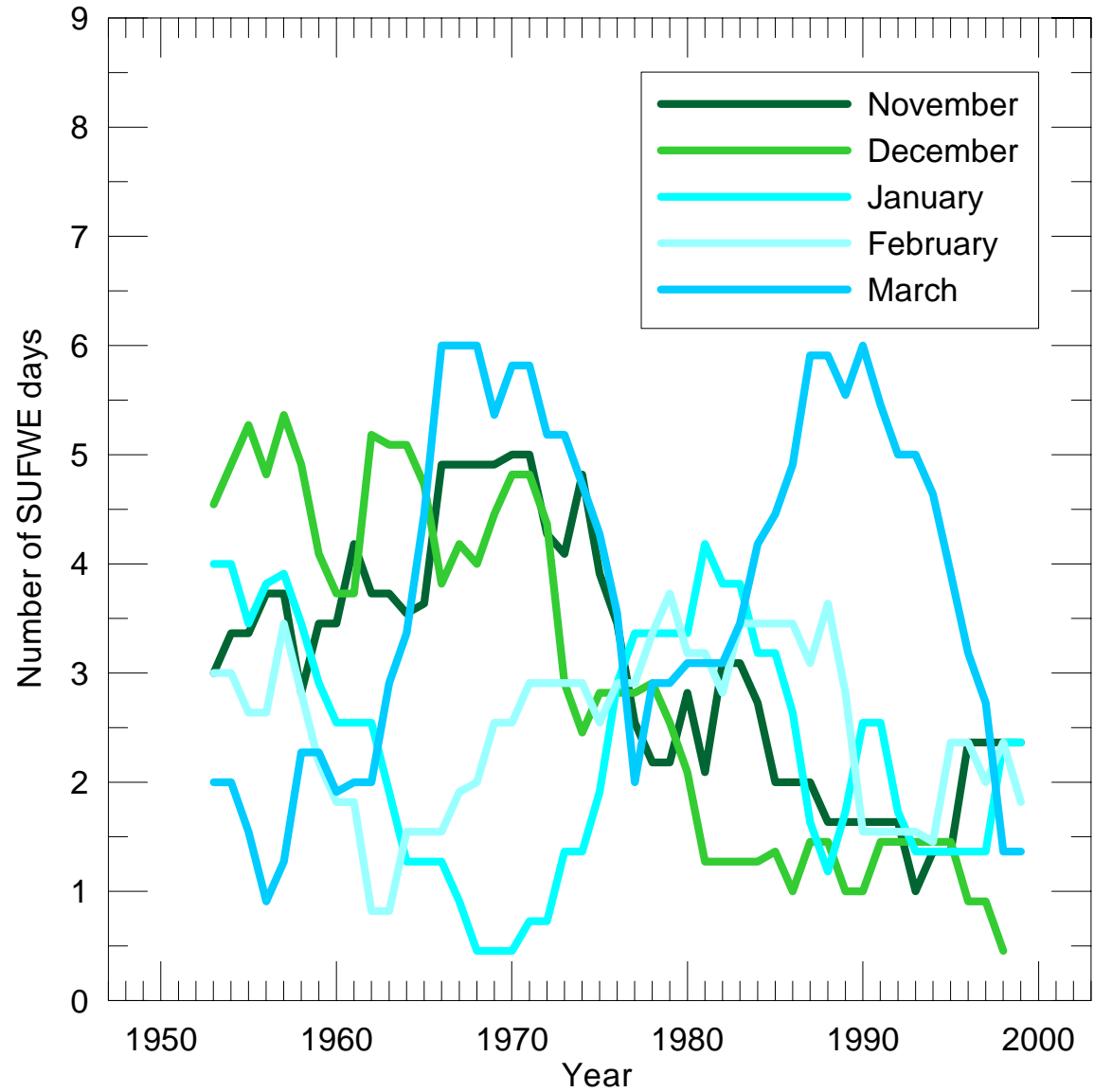

Fig. 4. 11-year running averages of the numbers of significantly upwelling-favourable days (SUFWE) for November, December, January, February and March, 1948-2003, at $41.0^{\circ} \mathrm{N}$, $9.4^{\circ} \mathrm{W}$.

\section{OSD}

2, 105-127, 2005

Western Iberian winter wind indices

E. Mason et al.

\section{Title Page}

Abstract

Introduction

Conclusions

References

Tables

Figures

14

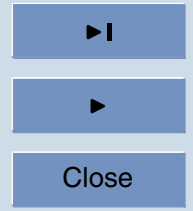

Back

Full Screen / Esc

Print Version

Interactive Discussion

EGU 


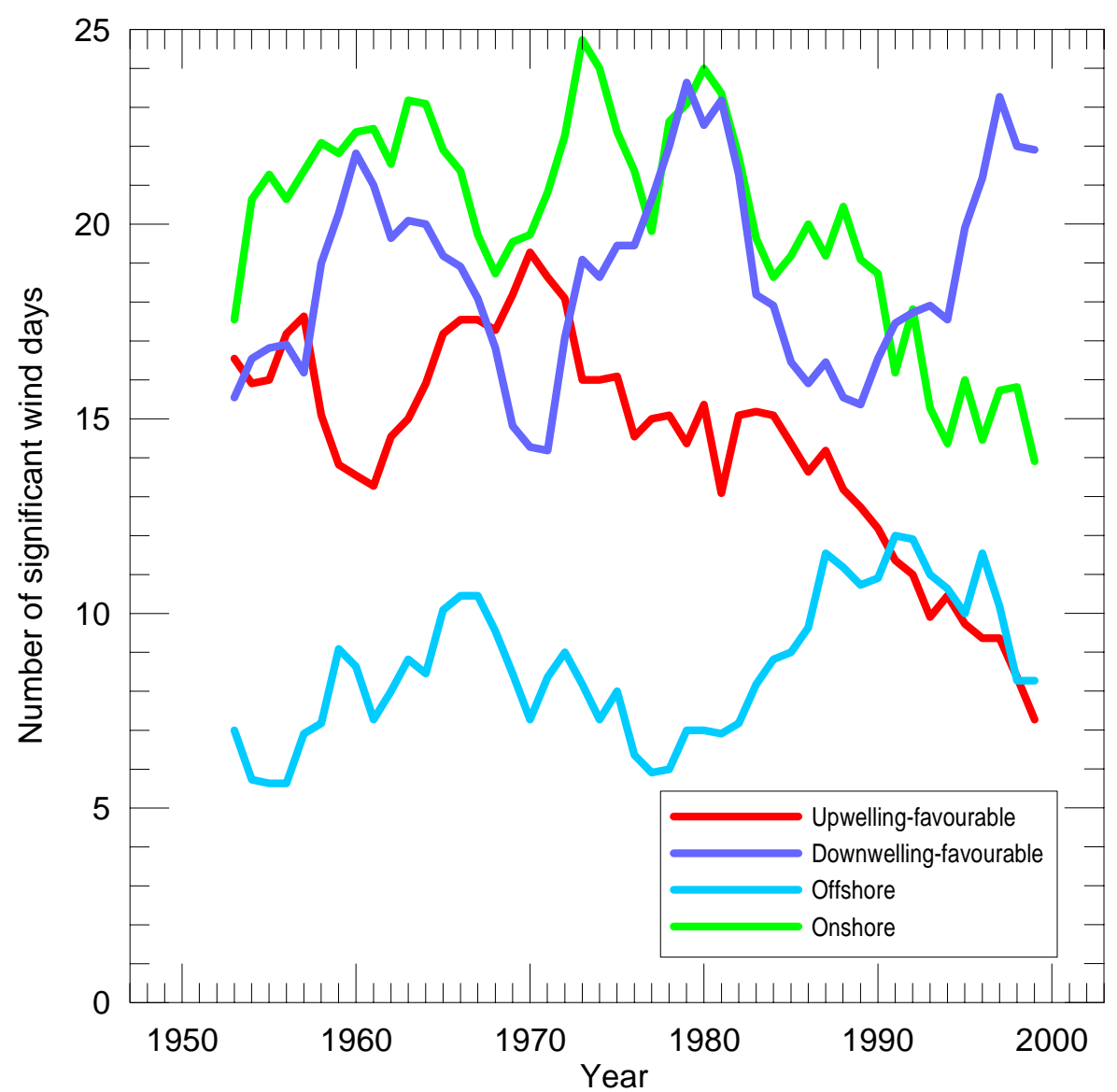

Fig. 5. 11-year running averages of the numbers of significantly upwelling-favourable, downwelling-favourable, onshore and offshore, days for November through March, 1948-2003, at $41.0^{\circ} \mathrm{N}, 9.4^{\circ} \mathrm{W}$.

\section{OSD}

2, 105-127, 2005

Western Iberian winter wind indices

E. Mason et al.

\section{Title Page}

\section{Abstract}

Introduction

Conclusions

References

Tables

Figures

14

4

Back

Close

\section{Full Screen / Esc}

Print Version

Interactive Discussion

EGU 


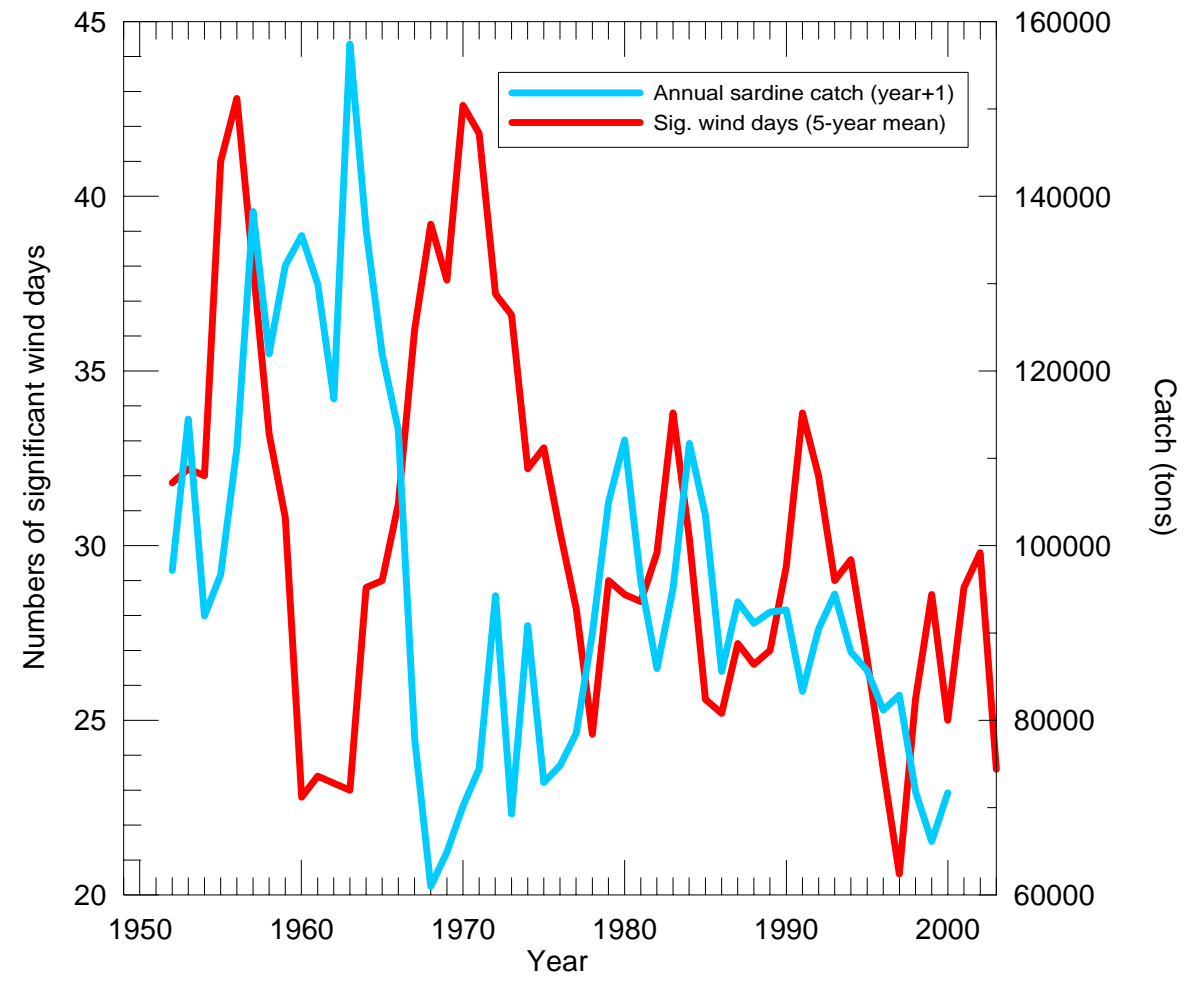

2, 105-127, 2005

Western Iberian winter wind indices

E. Mason et al.

Title Page

Abstract

Conclusions

Tables

References

Figures

14

4

Back

Fig. 6. Line plots comparing 5-year (backward) running averages of the hybrid wind index (numbers of significant northerly and offshore wind days) with annual Iberian sardine catch,

rint Version

Interactive Discussion

EGU 